\title{
IDENTIFIKASI Listeria spp. PADA PANGAN JAJANAN BERBASIS IKAN DI KOTA BOGOR
}

\author{
[Identification of Listeria spp. in Fish-based Snack in Bogor]
}

\author{
Elia Yuswita ${ }^{1)}$, Siti Nurjanah ${ }^{2,3)}$, dan Winiati P. Rahayu ${ }^{2,3) \star}$ \\ 1) Program Studi Ilmu Pangan, Sekolah Pasca Sarjana, Institut Pertanian Bogor, Bogor \\ ${ }^{2)}$ Departemen Ilmu dan Teknologi Pangan, Fakultas Teknologi Pertanian, Institut Pertanian Bogor, Bogor \\ ${ }^{3)}$ Southeast Asia Food and Agricultural Science and Technology Center, Institut Pertanian Bogor, Bogor
}

Diterima 28 Maret 2016 / Disetujui 10 Juni 2016

\begin{abstract}
L. monocytogenes contamination in processed food, especially fish-based snack, may results from contaminated raw materials, underprocessed or recontamination. The aims of this study were to identify the presence of Listeria spp. especially L. monocytogenes by PCR method and biochemical methods, as well as calculate the prevalence of Listeria spp. in fish-based snack food in Bogor. This study was conducted of 4 steps: (1) determination of L. monocytogenes's DNA limit detection, (2) sample preparation, (3) identification of L. monocytogenes with real-time PCR, and (4) identification of Listeria spp. with biochemical methods. The results showed that DNA detection limits of $L$. monocytogenes in fish meatball and otak-otak were at $8.3 \times 10^{2}$ and $2.9 \times 10^{2} \mathrm{CFU} / \mathrm{g}$, respectively. The study on 65 samples indicated that contamination of L. monocytogenes was not observed, but other species of Listeria spp., namely L. grayi and $L$. innocua, were found. The prevalence of $L$. grayi and $L$. innocua in siomay was at $5.9 \%$, while the prevalence of L. grayi in shrimp meatballs, fish meat balls, fried meatballs was at $8.3,9.1$, and $50 \%$, respectively. Furthermore, L. innocua from takoyaki samples with a prevalence of $20 \%$ was observed.
\end{abstract}

Keywords: fish-based snack, Listeria spp., L. monocytogenes

\section{ABSTRAK}

Kontaminasi L. monocytogenes pada pangan olahan khususnya pangan jajanan berbasis ikan dapat terjadi melalui bahan baku yang tercemar, pengolahan yang tidak sempurna atau rekontaminasi setelah pengolahan. Penelitian ini bertujuan untuk mengidentifikasi keberadaan Listeria spp. terutama L. monocytogenes dengan metode PCR dan metode biokimiawi, serta menghitung prevalensi Listeria spp. pada pangan jajanan berbasis ikan di kota Bogor. Penelitian ini dilakukan dalam empat tahap, meliputi penentuan limit deteksi DNA L. monocytogenes, persiapan sampel, identifikasi bakteri L. monocytogenes dengan real-time PCR, dan identifikasi Listeria spp. dengan metode biokimiawi. Hasil limit deteksi DNA L. monocytogenes pada bakso ikan dan otak-otak masing-masing adalah $8,3 \times 10^{2}$ dan $2,9 \times 10^{2} \mathrm{CFU} / \mathrm{g}$. Hasil analis is terhadap 65 sampel pangan jajanan berbasis ikan menunjukkan bahwa tidak ada cemaran $L$. monocytogenes pada pangan jajanan berbasis ikan, akan tetapi ditemukan $L$. grayi dan L. innocua. Prevalensi L. grayi dan $L$. innocua pada sampel siomay yang diuji masing-masing adalah $5,9 \%$. Pada sampel bakso udang, sampel bakso ikan, dan sampel bakso goreng ditemukan $L$. grayi dengan prevalensi 8,$3 ; 9,1$; dan $50 \%$, sedangkan $L$. innocua ditemukan pada sampel takoyaki dengan prevalensi sebesar $20 \%$.

Kata kunci: jajanan berbasis ikan, Listeria spp., L. monocytogenes

\section{PENDAHULUAN}

Listeria spp. merupakan bakteri Gram positif, katalase positif, berbentuk batang pendek, tidak membentuk spora, dan motil. Bakteri ini motil pada suhu $28^{\circ} \mathrm{C}$ dan tidak motil pada suhu $37^{\circ} \mathrm{C}$, tumbuh optimum pada suhu $30-37^{\circ} \mathrm{C}$ (Garrido et al., 2010).

*Penulis Korespondensi:

E-mail: wini_a@hotmail.com
Keberadaannya yang tersebar luas di alam patut dicermatimengingat kemampuannya untuk tumbuh pada berbagai kondisi ekstrim, seperti pada media dengan konsentrasi garam tinggi (10\%) (Campos et al., 2011), pH dengan kisaran 4,3-9,4 (Nadal et al., 2007) dan mampu hidup dalam waktu yang lama pada suhu $4^{\circ} \mathrm{C}$ (Kim dan Cho, 2010).

Beberapa spesies dari genus Listeria yang tersebar dialam adalah $L$. monocytogenes, $L$. innocua, L. seeligeri, L. welshimeri, L. ivanovii, dan L. grayi. 
Diantara spesies ini, yang bersifat patogen terhadap manusia adalah L. monocytogenes (Janzten et al., 2006). L. monocytogenes merupakan bakteri patogen yang ditemukan pada susu dan produk olahan susu, daging dan produk olahan daging, sayuran segar, ikan dan produk olahan ikan. Bakteri ini mampu membentuk biofilm dan realtif tahan terhadap pemanasan, pengeringan, dan pembekuan (Montero et al., 2015).

L. monocytogenes mampu menyebabkan penyakit pada hostnya dengan jumlah/dosis minimum infeksi $100 \mathrm{CFU} / g$. Serotipe L. monocytogenes yang menyebabkan kasus listeriosis pada manusia, diantaranya adalah $1 / 2$ a, 1/2 b, 1/2 c, dan 4b (Ragon et al., 2008). Sindrom klinis yang ditimbulkan oleh strain bakteri L. monocytogenes umumnya bertanggung jawab atas dua tipe infeksi pada manusia, yaitu bersifat invasif dan non-invasif. Listeriosis non-invasif atau disebut juga listerial gastroenteritis (listeriosis bentuk saluran pencernaan) menunjukkan gejala penyakit yang ringan, seperti mual, muntah, kram perut, dan diare. Listeriosis invasif diakui sebagai foodborne disease yang serius karena tingkat keparahan gejala dan tingkat kematian yang tinggi yaitu 20-30\%. Sindrom klinis yang ditimbulkan oleh listeriosis bentuk invasif yaitu septikemia, meningitis, maningoensefalitis, dan dapat mengakibatkan keguguran pada wanita hamil, kematian pada bayi yang baru lahir atau persalinan prematur (Garrido et al., 2010).

Tocmo et al. (2014) mengatakan bahwa ikan atau produk olahannya dapat terkontaminasi oleh polusi limbah baik dari lingkungan hidup ikan tersebut atau pada saat proses pengolahan. Ikan merupakan salah satu bahan pangan yang dapat dengan mudah terkontaminasi bakteri. Beberapa pangan olahan berbasis ikan yang umumnya ditemukan di lingkungan sekolah adalah siomay, otak-otak, bakso udang, bakso ikan, takoyaki, pempek, dan bakso goreng. Cemaran dapat bersumber dari ikan yang digunakan ataupun selama dan pasca proses pengolahan.

Penelitian ini bertujuan untuk mengidentifikasi keberadaan Listeria spp. terutama $L$. monocytegenes dengan metode PCR dan metode biokimiawi, serta menghitung prevalensi Listeria spp. pada pangan jajanan berbasis ikan di kota Bogor. Diharapkan data mengenai identitas dan prevalensi Listeria spp. terutama $L$. monocytogenes dapat digunakan sebagai dasar ilmiah bagi pengembangan program keamanan pangan.

\section{BAHAN DAN METODE}

\section{Bahan}

Bahan utama yang digunakan dalam penelitian ini adalah sampel pangan jajanan berbasis ikan (siomay, otak-otak, bakso udang, bakso ikan, takoyaki, pempek, dan bakso goreng) yang diambil dilingkungan sekolah. Pengambilan sampel dilakukan secara proporsional sesuai keters ediaan sampel yang dijual pedagang di setiap lokasi sekolah di kota Bogor. Jumlah sampel dan sebaran tempat pengambilan sampel disajikan dalam Tabel 1. Berdasarkan laporan Rahayu et al. (2015), diketahui bahwa proporsi pangan jajanan berbasis ikan yang dijual di lingkungan sekolah di kota Bogor didominasi oleh siomay yaitu sebesar $26 \%$. Selanjutnya diikuti oleh otak-otak (19\%), sate, olahan (bakso udang, bakso ikan, dan takoyaki) (15\%), pempek (7\%), dan bakso goreng (6\%). Sampel pangan jajanan berbasis ikan yang dianalisis adalah sampel matang yang telah diolah dengan cara dibakar, direbus/dikukus, dan digoreng.

Tabel 1. Jumlah sampel dan sebaran tempat pengambilan sampel

\begin{tabular}{|c|c|c|c|}
\hline Kecamatan & $\begin{array}{c}\text { Tingkat } \\
\text { Sekolah }\end{array}$ & $\begin{array}{c}\text { Jumlah } \\
\text { Pedagang }\end{array}$ & $\begin{array}{l}\text { Jumlah } \\
\text { Sampel }\end{array}$ \\
\hline Bogor Selatan & $\overline{\mathrm{PT}}$ & 4 & 6 \\
\hline \multirow[t]{2}{*}{ Bogor Timur } & SLTA & 4 & 6 \\
\hline & PT & 2 & 3 \\
\hline \multirow[t]{2}{*}{ Bogor Utara } & SD & 1 & 1 \\
\hline & SLTA & 1 & 1 \\
\hline \multirow[t]{3}{*}{ Bogor Tengah } & SD & 4 & 6 \\
\hline & SLTA & 8 & 9 \\
\hline & PT & 2 & 1 \\
\hline \multirow[t]{3}{*}{ Bogor Barat } & SD & 8 & 10 \\
\hline & SLTP & 4 & 5 \\
\hline & SLTA & 7 & 8 \\
\hline \multirow[t]{3}{*}{ Tanah Sareal } & SD & 2 & 4 \\
\hline & SLTP & 1 & 2 \\
\hline & PT & 2 & 3 \\
\hline Total & & 50 & 65 \\
\hline
\end{tabular}

Keterangan:

PT : Perguruan Tinggi

SLTA : Sekolah LanjutanTingkat atas

SLTP : Sekolah Lanjutan Tingkat Pertama

SD : Sekolah Dasar

Penentuan limit deteksi DNA L. monocytogenes (Mutsyahidan et al., 2016)

Pengujian limit deteksi DNA L. monocytogenes dilakukan untuk mengetahui sensitivitas metode yang digunakan untuk mendeteksi DNA L. monocytogenes yang di spikeke sampel pangan. Sampel pangan digolongkan dalam tiga kategori yaitu dibakar (bakso udang, bakso ikan, dan takoyaki), direbus/dikukus (siomay dan otak-otak), dan digoreng (pempek dan bakso goreng). Limit deteksi dihitung untuk pangan yang dibakar dan direbus/ dikukus. Sampel pangan yang diolah dengan cara dibakar diwakili oleh bakso ikan, dan sampel pangan yang diolah dengan cara direbus/dikukus diwakili oleh otak-otak. Limit deteksi untuk pangan yang digoreng diwakili oleh pempek dan telah dihitung oleh Mutsyahidan et al. (2016). 
Penentuan limit deteksi diawali dengan menyegarkan $0,1 \mathrm{~mL}$ kultur bakteri $L$. monocytogenes strain ATCC 7644 (ATCC, USA) dengan konsentrasi $10^{2} \mathrm{CFU} / \mathrm{mL}$ kedalam 8,9 mL Tryptone Soy Broth yeast extract (TSBye) (Oxoid, Inggris) dan diinkubasi dalam inkubator (Memmert, German) pada suhu $37^{\circ} \mathrm{C}$ selama 18 jam. Suspensi bakteri tersebut $\left(10^{8} \mathrm{CFU} / \mathrm{mL}\right)$ ditambahkan ke dalam media Buffered Peptone Water (BPW) (Oxoid, Inggris) steril dan dikocok hingga homogen. Berikutnya masing-masing sampel bakso ikan dan otak-otak sebanyak $25 \mathrm{~g}$ yang telah dihancurkan ditambah dengan $75 \mathrm{~mL}$ suspensi bakteri $\left(10^{7} \mathrm{CFU} / \mathrm{mL}\right)$ dan dikocok hingga homogen. Selanjutnya dari masingmasing larutan sampel tersebut sebanyak $1 \mathrm{~mL}$ dibuat seri pengenceran hingga diperoleh suspensi dengan konsentrasi bakteri $10^{1}-10^{6} \mathrm{CFU} / \mathrm{mL}$, dan ditumbuhkan $\left(37^{\circ} \mathrm{C}, 48 \mathrm{jam}\right)$ pada media Cromocult ®Listeria Selective Agar Base acc Ottaviani and Agosti (ALOA) (Merck, Jerman). Selain itu, dari masing-masing larutan sampel tersebut diambil sebanyak $1 \mathrm{~mL}$ dan dipindahkan ke dalam microtube (ExtraGene, Taiwan) untuk dilakukan ekstraksi DNA-nya. Ekstraksi DNA dilakukan dengan metode fenol klorofom dan hasil ekstraksi diamplifikasi dengan real-time PCR (rt-PCR) Swift ${ }^{\text {TM }}$ Spectro 48 (ESCO, Singapura). Amplifikasi DNA secara otomatis akan digambarkan dalambentuk grafik amplifikasi dan kurva standar menggunakan software IQ-5 (BioRad).

Limit deteksi ditentukan berdasarkan nilai threshold cycle $\left(\mathrm{C}_{\mathrm{T}}\right)$ amplikon. Nilai $\mathrm{C}_{\mathrm{T}}$ adalah siklus diatas noise (background fluorescence) dimana akumulasi produk (senilai $2 n, n$ ialah jumlah pengulangan siklus amplifikasi) terbaca pertama kali pada fase eksponensial. Kurva standar menghasilkan persamaan linear hubungan antara log konsentrasi bakteri dan threshold cycle $\left(\mathrm{C}_{\mathrm{T}}\right)$. Persamaan linear kurva standar dapat digunakan untuk menghitung konsentrasi bakteri yang belum diketahui dalam sampel pangan. Konsentrasi $L$. monocytogenes pada sampel pangan jajanan berbasis ikan dihitung dengan memasukkan nilai $\mathrm{C}_{\mathrm{T}}$ hasil amplifikasi sebagai nilai y pada persamaan linear $(y=a x+b)$, kemudian nilai $x$ yang diperoleh diantilogkan.

\section{Persiapan Sampel (BAM, 2011)}

Tahapan persiapan sampel mengacu pada BAM (2011) dengan modifikasi. Modifikasi yang dilakukan adalah jumlah media Listeria Enrichment Broth Base yang digunakan (dari 225 menjadi 75 $\mathrm{mL}$ ), dan modifikasi waktu inkubasi (dari 24 menjadi 18 jam). Sampel pangan jajanan berbasis ikan sebanyak $25 \mathrm{~g}$ dimasukkan ke dalam kantong steril secara aseptis, dihancurkan, dan ditambah dengan $75 \mathrm{~mL}$ media Listeria Enrichment Broth Base (Oxoid, Inggris), dikocok hingga homogen. Berikutnya larutan sampel dipindahkan ke dalam botol bertutup steril dan diinkubasi pada suhu $30^{\circ} \mathrm{C}$ selama 4 jam dan ditambah $1 \mathrm{~mL}$ Listeria Selective Enrichment Supplement (Oxoid, Inggris). Inkubasi dilanjutkan pada suhu $30^{\circ} \mathrm{C}$ selama 18 jam. DNA dalam sampel siap diekstrak.

\section{Identifikasi bakteri $L$. monocytogenes dengan real-time PCR (rt-PCR) (Mutsyahidan et al., 2016)}

Sebanyak $1 \mathrm{~mL}$ sampel disentrifus dengan kecepatan $12.000 \mathrm{rpm}$ pada suhu $25^{\circ} \mathrm{C}$ selama 3 menit. Selanjutnya dilakukan resuspensi dengan $500 \mu \mathrm{L}$ bufer tris-ETDA (TE) 1x untuk memisahkan komponen pangan dengan DNA bakteri target. Berikutnya tahapan pelisisan sampel dilakukan menggunakan $100 \mu \mathrm{L}$ lisozim (Bio Basic, Canada), $25 \mu \mathrm{L}$ larutan sodium dodecyl sulfate 10\% (Merck, Jerman), $50 \mu \mathrm{l} \mathrm{NaCl}$ (Merck, Jerman) 5M, dan $100 \mu \mathrm{L}$ proteinase K (Peqlab, Jerman). Pada tahapan ini juga ditambahkan $500 \mu \mathrm{L}$ bufer TE 1x untuk proteksi dan stabilisasi DNA. Kemudian ditambahkan $250 \mu \mathrm{L}$ fenol (MP Bio, US), $250 \mu \mathrm{L}$ kloroform (J.T. Baker, Meksiko) dan disentrifugasi pada kecepatan $12.000 \mathrm{rpm}$ pada suhu $4^{\circ} \mathrm{C}$ selama 10 menit untuk memisahkan DNA dari debris sel. Setelah itu dilakukan tahapan presipitasi DNA dengan menambahkan $500 \mu \mathrm{L}$ isopropanol (Merck, Jerman) dan $150 \mu \mathrm{L}$ amonium asetat $10 \mathrm{M} \mathrm{pH} \mathrm{7,4}$ (Merck, Jerman). Selanjutnya dilakukan pencucian DNA menggunakan $500 \mu \mathrm{L}$ etanol 70\% (Merck, Jerman). Pelet yang diperoleh dikering udarakan, ditambah dengan $50 \mu \mathrm{L}$ bufer TE $1 \mathrm{x}$, dan siap untuk dilakukan amplifikasi DNA. Amplifikasi dilakukan dengan menggunakan alat rt-PCR. Hasil positif deteksi $L$. monocytogenes pada sampel ditandai dengan terbentuknya grafik sigmoidal proses amplifikasi seperti dijelaskan pada penentuan limit deteksi.

\section{Identifikasi bakteri Listeria spp. dengan metode biokimiawi (BAM, 2011)}

Sebanyak $100 \mu \mathrm{L}$ dari kultur pengayaan ditumbuhkan pada media ALOA dan diinkubasi pada suhu $37^{\circ} \mathrm{C}$ selama 48 jam. Listeria spp. diisolasi dari koloni bewarna hijau-biru yang tumbuh pada media ALOA. Isolat terduga Listeria spp selanjutnya diuji dengan uji katalase, pewarnaan Gram, uji motilitas, uji hemolitik, dan uji fermentasi karbohidrat.

\section{HASIL DAN PEMBAHASAN}

\section{Limit deteksi DNA L. monocytogenes}

Limit deteksi merupakan jumlah terkecil dalam sampel yang dapat dideteksi, yang menunjukkan sensitivitas dari suatu metode. Limit deteksi dari hasil pengujian menggunakan rt-PCR menunjukkan jumlah terkecil DNA yang masih dapat teramplifikasi 
dari pengenceran tertinggi. Berdasarkan hasil analisis limit deteksi DNA L. monocytogenes pada bakso ikan dan otak-otak menggunakan it-PCR (Tabel 2), diketahui bahwa masing-masing sampel memiliki limit deteksi sebesar $8,3 \times 10^{2}$ dan $2,9 \times 10^{2} \mathrm{CFU} / \mathrm{g}$. Limit deteksi DNA $L$. monocytegenes pada sampel bakso ikan dan otak-otak lebih rendah daripada limit deteksi pempek, yaitu sebesar $6,3 \times 10^{3} \mathrm{CFU} / \mathrm{g}$ (Mutsyahidan et al., 2016). Hal ini menunjukkan bahwa pengujian $L$. monocytogenes pada sampel bakso ikan dan otak-otak dengan itPCR memberikan hasil yang lebih sensitif daripada sampel pempek.

Tabel 2. Hasil analisis limit deteksi DNA L. monocytogenes pada bakso ikan dan otak-otak berdasarkan nilai $\mathrm{C}_{\mathrm{T}}$ menggunakan rt-PCR

\begin{tabular}{ccc}
\hline $\begin{array}{c}\text { Nama Pangan } \\
\text { Jkan }\end{array}$ & $\begin{array}{c}\text { Jumlah Koloni } \\
(\mathrm{CFU} / \mathrm{g})\end{array}$ & $\begin{array}{c}\text { Rerata Nilai } \\
\mathrm{C}_{\mathrm{T}} \pm \mathrm{SD}^{1}\end{array}$ \\
\hline Bakso Ikan & $4,9 \times 10^{\circ}$ & $9,16 \pm 0,56$ \\
& $4,0 \times 10^{\circ}$ & $12,34 \pm 1,32$ \\
& $5,8 \times 10^{4}$ & $15,00 \pm 0,04$ \\
& $4,1 \times 10^{\circ}$ & $18,51 \pm 0,02$ \\
& $8,3 \times 10^{\circ}$ & $24,36 \pm 0,33$ \\
& $<1,0 \times 10^{\prime}$ & - \\
& $<1,0 \times 10^{\prime}$ & - \\
& & \\
& $5,4 \times 10^{\prime}$ & $9,24 \pm 0,26$ \\
Otak-otak & $2,3 \times 10^{\circ}$ & $11,82 \pm 0,31$ \\
& $2,0 \times 10^{\circ}$ & $15,62 \pm 0,40$ \\
& $3,0 \times 10^{4}$ & $19,84 \pm 0,49$ \\
& $2,9 \times 10^{\circ}$ & $21,04 \pm 0,16$ \\
& $2,9 \times 10^{\circ}$ & $23,96 \pm 0,81$ \\
& $<1,0 \times 10^{\prime}$ & - \\
\hline
\end{tabular}

Keterangan:1) $\mathrm{n}=2$

Perbedaan ini terjadi karena ekstraksi pada sampel pempek lebih sulit dilakukan dibandingkan ekstraksi pada sampel bakso ikan dan otak-otak. Pempek teksturnya lebih padat, lengket, dan kenyal. Pempek yang dianalisis dibuat dari tepung sagu sedangkan bakso ikan dan otak-otak dibuat dari tepung tapioka. Tepung sagu mengandung amilosa $(27 \%)$ yang lebih besar daripada amilosa pada tepung tapioka (17\%) (Kusnandar, 2010). Karakteristik amilosa yang mampu membentuk gel yang sangat kuat diduga berpengaruh terhadap hasil ekstraksi. Selanjutnya hasil ekstraksi berpengaruh terhadap hasil amplifikasi, karena semakin banyak sel $L$. monocytogenes yang terakumulasi pada saat ekstraksi, menyebabkan proses amplifikasi DNA semakin cepat terjadi, sehingga nilai threshold cycle $\left(\mathrm{C}_{\mathrm{T}}\right.$ ) yang diperoleh juga semakin kecil. Queero et al. (2014) melaporkan bahwa semakin tinggi konsentrasi DNA $L$. monocytogenes yang terekstrak, maka proses amplifikasi yang terjadi juga semakin cepat. Hasil analisis (Tabel 2) digunakan untuk membuat kurva standar.

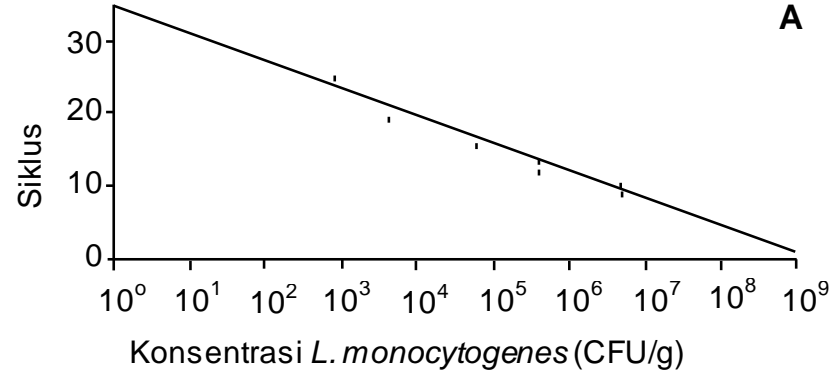

Perpotongan dengan sumbu $Y 33,75$

Kemiringan $-3,79$

Galat 0,081

Koefisien korelasi $-0,973$

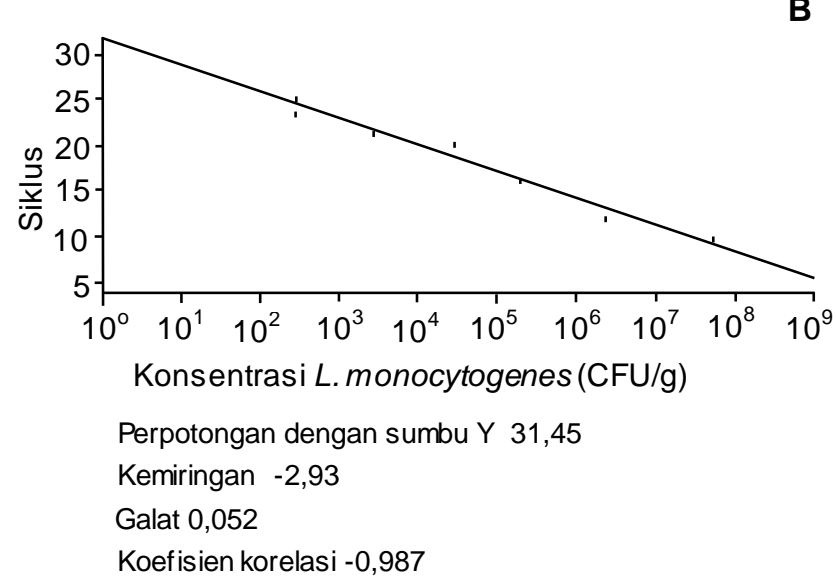

Gambar 1. Kurva standar hubungan nilai $\mathrm{C}_{\mathrm{T}}$ dan log konsentrasi $L$. monocytogenes pada: A. Bakso ikan, dan B. Otak-otak

Kurva standar (Gambar 1) menghasilkan persamaan $\mathrm{C}_{\mathrm{T}}=33,75-3,79 \mathrm{C}$ untuk sampel bakso ikan, dan $\mathrm{C}_{\mathrm{T}}=31,45-2,93$ Cuntuk sampel otak-otak. C adalah nilai konsentrasi bakteri pada sampel pangan. Nilai koefisien korelasi dari persamaan tersebut adalah $-0,973$ dan $-0,987$. Idealnya nilai koefisien korelasi adalah $+/-1.0$, namun nilai koefisien korelasi uji sudah menggambarkan hubungan yang sangat kuat antara nilai $C_{T}$ dan konsentrasi $L$. monocytogenes. Nilai korelasi yang negatif menunjukkan bahwa semakin besar nilai pada sumbu $x$ (konsentrasi L. monocytogenes) maka semakin kecil nilai pada sumbu y (nilai $\mathrm{C}_{\mathrm{T}}$ ).

\section{Hasil identifikasi bakteri $L$. monocytogenes dengan real-time PCR (rt-PCR)}

Hasil identifikasi menggunakan it-PCR menunjukkan bahwa tidak ditemui cemaran L. monocytogenes pada 65 sampel pangan jajanan berbasis ikan. Kontaminasi L. monocytogenes pada produk pangan siap saji dapat terjadi melalui bahan bakunya, komposisi bahan tambahan yang digunakan, peralatan pengolahan yang tidak bersih, 
proses pemasakan yang tidak cukup, dan rekontaminasi setelah pengolahan. Selain itu, penyimpanan yang lama pada suhu refrigerator (suhu $4^{\circ} \mathrm{C}$ ) juga berpengaruh terhadap keberadaan L. monocytogenes. Ikan yang merupakan bahan baku pengolahan pangan jajanan berbasis ikan mungkin sudah terkontaminasi L. monocytogenes. Jallewar et al. (2007) menemukan prevalensi $L$. monocytogenes pada ikan sebesar 13\%. Pada penelitian ini tidak ditemukan L. monocytogenes pada pangan jajanan berbasis ikan kemungkinan karena penggunaan ikan sebagai bahan baku bermutu baik, ataupun karena jumlah ikan yang digunakan hanya sekitar 10-20\%. Kecilnya persentase ikan juga akan berpengaruh pada kemungkinan adanya $L$. monocytogenes pada sampel.

Bahan tambahan pangan yang digunakan pada pengolahan pangan jajanan berbasis ikan adalah garam dan rempah-rempah. Garam hanya ditambahkan sampai rasa asin sudah terasa secara sensori (2,0-2,5\%), sedangkan rempah-rempah yang ditambahkan adalah bawang putih (5\%). Kecilnya persentase garam dan bawang putih yang ditambahkan menyebabkan tidak banyak pengaruhnya pada ketidakberadaan $L$. monocytogenes pada produk. L. monocytogenes mampu tumbuh dalam media dengan konsentrasi garam tinggi yaitu 10\% (Campos et al., 2011). Selain itu, keberadaan $L$. monocytogenes dalam pangan juga dapat dipengaruhi oleh proses pengolahan. Sampel pangan jajanan berbasis ikan diolah dengan cara dibakar, direbus/dikukus, dan digoreng. Perlakuan ini dapat menghilangkan dan membunuh $L$. monocytogenes. Proses pemanasan pada suhu $66^{\circ} \mathrm{C}$ selama 18 detik dapat membunuh $90 \%$ populasi L. monocytogenes (Shi et al., 2015). Sebagian besar penjaja (53\%) sudah memasak bahan baku jauh sebelum waktu berjualan ( $>4$ jam oleh $85 \%$ penjaja), dan penjaja $(72 \%)$ meletakkan pangan olahan di suhu ruang $\left(30^{\circ} \mathrm{C}\right)$. Tahapan penyajian ini merupakan titik kritis karena lokasi di sekitar tempat berjualan kotor (Rahayu et al., 2015). Waktu tunda antara pengolahan dan pengambilan sampel berkisar antara 4-6 jam, meskipun demikian rekontaminasi $L$. monocytogenes juga tidak terjadi.

Faktor lainnya yang menjadi penyebab $L$. monocytogenes tidak ditemukan pada sampel pangan jajanan berbasis ikan adalah kompetisi mikroba. Berdasarkan pengujian biokimiawi ditemukan spesies Listeria spp. seperti L. grayi dan L. innocua. Adanya kedua jenis mikroba tersebut dapat menekan pertumbuhan L. monocytogenes (Zilelidou et al., 2015). L.innocua telah diidentifikasi sebagai antagonis yang berpotensi menekan pertumbuhan $L$. monocytogenes dalam medium pengayaan (Besse et al., 2010).
L. monocytogenes telah ditemukan pada berbagai produk pangan siap saji di luar negeri seperti di Spanyol. Berdasarkan hasil pengujian dengan rt-PCR, ditemukan $L$. monocytogenes dengan tingkat cemaran sebesar $1,4 \times 10^{2}$ dan $4,4 \times 10^{5} \mathrm{CFU} / \mathrm{g}$ pada 25 sampel summer salad dan 28 sampel valencian salad (Berrada et al., 2006). Keberadaan L. monocytogenes juga ditemukan pada berbagai produk pangan siap saji lainnya, seperti produk olahan ikan (pie ikan dan ikan asap), produk olahan daging (pork luncheon, kroket ayam, sosis, ham, turkey breast), produk olahan susu (keju), produk dishes dan desserts) di Spanyol dengan tingkat cemaran sebesar <10 - >100 CFU/g (Cabedo et al., 2008).

\section{Hasil identifikasi bakteri Listeria spp. dengan metode biokimiawi}

Berdasarkan hasil uji morfologi dan biokimia pada sampel pangan jajanan berbasis ikan (Tabel 3), diketahui prevalensi Listeria spp. nya rendah (Tabel 4). L. grayi dan L. innocua yang ditemukan pada sampel pangan berbasis ikan merupakan spesies Listeria yang tidak berbahaya. Prevalensi $L$. grayi dan $L$. innocua pada sampel siomay adalah $5,9 \%$. Berikutnya ditemukan $L$. grayi pada sampel bakso udang dengan prevalensi masing-masing 8,3 dan $9,1 \%$ pada sampel bakso ikan. L. grayi juga ditemukan pada sampel bakso goreng dengan prevalensi $50 \%$, dan $L$. innocua pada sampel takoyaki dengan prevalensi $20 \%$. Ditemukannya L. grayi dan $L$. innocua pada sampel siomay mengindikasikan bahwa kemungkinan kontaminasi terjadi akibat penanganan (penyimpanan) bahan baku yang belum baik ataupun karena terjadi rekontaminasi. Rahayu et al. (2015) melaporkan bahwa pedagang $(63,8 \%)$ belum melakukan penyimpanan bahan segar dengan baik, dan belum mempraktikkan penyimpanan dingin. Rekontaminasi juga dapat terjadi setelah pengolahan baik dari peralatan pengolahan yang tidak bersih maupun dari tangan penjamah (pedagang). Rekontaminasi setelah pengolahan juga dilaporkan oleh Holch et al. (2013), yang menemukan Listeria spp. pada makanan yang sudah diolah (ikan asap).

Sampel bakso udang, bakso ikan dan takoyaki merupakan pangan jajanan berbasis ikan yang diolah dengan cara dibakar. Ditemukannya $L$. grayi pada sampel bakso udang dan bakso ikan, serta L. innocua pada sampel takoyaki disebabkan karena terjadinya rekontaminasi setelah pengolahan pada tahap penyajian yang dibiarkan terbuka pada suhu ruang. Bakso udang dan bakso ikan merupakan produk pangan siap saji yang biasanya jika tidak habis terjual disimpan di dalam lemari es untuk dijual keesokan harinya. 
Tabel 3. Uji morfologi dan biokimia Listeria spp. sampel pangan jajanan berbasis ikan

\begin{tabular}{|c|c|c|c|c|c|c|c|c|}
\hline $\begin{array}{c}\text { Jenis } \\
\text { Sampel }\end{array}$ & $\begin{array}{l}\text { Sifat Gram dan } \\
\text { Bentuk Sel }\end{array}$ & Motilitas & Katalase & Manitol & Xylosa & Rhamnosa & Hemolitik & Kesimpulan \\
\hline \multirow[t]{2}{*}{ Siomay } & $\begin{array}{c}\text { Gram +, } \\
\text { coccobasil }\end{array}$ & + & + & + & - & - & - & L. grayi \\
\hline & $\begin{array}{c}\text { Gram +, } \\
\text { coccobasil }\end{array}$ & + & + & - & - & - & - & L. innocua \\
\hline $\begin{array}{l}\text { Bakso } \\
\text { udang }\end{array}$ & $\begin{array}{c}\text { Gram +, } \\
\text { coccobasil }\end{array}$ & + & + & + & - & - & - & L. grayi \\
\hline $\begin{array}{l}\text { Bakso } \\
\text { ikan }\end{array}$ & $\begin{array}{c}\text { Gram +, } \\
\text { coccobasil }\end{array}$ & + & + & + & - & - & - & L. grayi \\
\hline Takoyaki & $\begin{array}{c}\text { Gram +, } \\
\text { coccobasil }\end{array}$ & + & + & - & - & - & - & L. innocua \\
\hline $\begin{array}{l}\text { Bakso } \\
\text { goreng }\end{array}$ & $\begin{array}{l}\text { Gram +, } \\
\text { coccobasil }\end{array}$ & + & + & + & - & - & - & L. grayi \\
\hline
\end{tabular}

Tabel 4. Prevalensi Listeria spp. pada pangan jajanan berbasis ikan

\begin{tabular}{lcccc}
\hline \multirow{2}{*}{ Jenis Sampel } & Jumlah Sampel & \multicolumn{3}{c}{ Prevalensi Jumlah Sampel Positif (\%) } \\
\cline { 3 - 5 } & & L. monocytogenes & L. grayi & L. innocua \\
\hline Siomay & 17 & 0 & 5,9 & 5,9 \\
Otak-otak & 15 & 0 & 0 & 0 \\
Bakso Udang & 12 & 0 & 8,3 & 0 \\
Bakso lkan & 11 & 0 & 9,1 & 0 \\
Takoyaki & 5 & 0 & 0 & 20 \\
Pempek & 3 & 0 & 0 & 0 \\
Bakso goreng & 2 & 0 & 50 & 0 \\
\hline Total & 65 & & & \\
\hline
\end{tabular}

Kedua jenis Listeria ini dapat bertahan hidup meskipun bahan disimpan dalam lemari es, karena bakteri ini mampu hidup dalam waktu yang lama pada suhu $4^{\circ} \mathrm{C}$. L. innocua yang ditemukan pada sampel takoyaki mengindikasikan bahwa proses pengolahan pangan tidak cukup untuk bahan baku (gurita) pada jajanan ini. Takoyaki umumnya hanya dimasak setengah matang dengan cara dibakar. Pada sampel bakso goreng yang diolah hingga matang, ditemukan $L$. grayi kemungkinan karena rekontaminasi setelah pengolahan. Lokasi penjualan dan tempat yang kotor serta tangan pedagang yang tidak higenis dapat menjadi penyebab rekontaminasi.

Listeria spp. tidak ditemukan pada sampel otakotak dan pempek yang dianalisis. Hal ini disebabkan karena kedua produk ini selalu dipanaskan atau disajikan dalam kondisi panas. Sampel otak-otak selalu dikukus selama penjualan, dan sampel pempek selalu digoreng matang sesaat sebelum disajikan. Takoyaki diletakkan terbuka cukup lama pada suhu ruang $\left(30^{\circ} \mathrm{C}\right)$ sebelum disajikan (Rahayu et al., 2015).

\section{KESIMPULAN}

Pada penelitian ini tidak ditemukan cemaran $L$. monocytogenes pada 65 jenis pangan jajanan berbasis ikan yang dideteksi dengan rt-PCR maupun yang diuji secara biokimiawi. Pada sampel siomay, bakso udang, bakso ikan, dan bakso goreng ditemukan $L$. grayi dengan prevalensi $5,9-50 \%$, sedangkan pada sampel siomay dan takoyaki ditemukan $L$. innocua dengan prevalensi $5,9-20 \%$. Penelitian deteksi L. monocytogenes pada pangan perlu dilakukan dengan metode molekuler lainnya seperti teknik Pulsed Field Gel Electrophoresis (PFGE), Amplified Fragment Length Polymorphism (AFLP), dan Random Amplified Polymorphic DNA (RAPD).

\section{UCAPAN TERIMAKASIH}

Pada kesempatan ini diucapkan terima kasih kepada Direktorat Jenderal Pendidikan Tinggi yang telah memberikan dana penelitian dengan skema Hibah Kompetensi melalui Surat Perintah Kerja No. 083/SP2H/PL/Dit.litabmas/ll/2015 tertanggal 05 Februari 2015, atas nama Prof. Dr. Winiati P.Rahayu. 


\section{DAFTAR PUSTAKA}

[BAM] Bacterial Analytical Manual. 2011. Chapter 10 detection and enumeration of Listeria monocytogenes in foods. Food and Drug Administration. www.fda.gov. [23 November 2014].

Berrada H, Soriano JM, Pico Y, Manes J. 2006. Quantification of Listeria monocytogenes in salads by real time quantitative PCR. Int J Food Microbiol 107: 202-206. DOI: 10.1016/j.ijfood micro.2005.07.006.

Besse NG, Barre L, Buhariwalla C, Vignaud ML, Khamissi E, Decours eulles E, Nirsimloo M, Chelly M, Kalmok off M. 2010. The overgrowth of Listeria monocytogenes by other Listeria spp. in food samples undergoing enrichment cultivation has a nutritional basis. Int $\mathrm{J}$ Food Microbiol 136: 345-351. DOI: 10.1016/j.ijfood micro.2009.10.025.

Cabedo L, Picart BL, Teixido CA. 2008. Prevalence of Listeria monocytogenes and Salmonella in ready-to-eat food in Catalonia, Spain. J Food Prot 71: 855-9.

Campos CA, Castro MP, Gliemmo MF, Schelegueda LI. 2011. Use of Natural Antimicrobials for The Control of Listeria monocytogenes in Foods. 1112-1123. Mendez-Vilaz A Ed. Formatex. Spanyol.

Garrido V, Vitas Al, Garcia-Jalon I. 2010. The Problem of Listeriosis and Ready-to-Eat Products: Prevalence and Persistence. 11821189. Mendez-Vilaz A Ed. Formatex. Spanyol.

Holch A, Webb K, Lukjancenko O, Ussery D, Rosenthal BM, Gram L. 2013. Genome sequencing identifies two nearly unchanged strains of persistent Listeria monocytogenes isolated at two different fish processing plants sampled 6 years apart. Appl Environ Microb 79: 29442951. DOI: 10.1128/AEM.03715-12.

Jallewar PK, Kalorey DR, Kurkure NV, Pande VV, Barbuddhe SB. 2007. Genotypic characterization of Listeria spp. isolated from fresh water fish. Int J Food Microbiol 114: 120-130. DOI: 10.1016/j.ijfoodmicro.2006.09.034.

Janzten MM, Navas J, Corujo A, Moreno R, Lopez V, Martinez-Suarez JV. 2006. Review. Spesific detection of Listeria monocytogenes in foods using commercial methods: from chromogenic media to real time PCR. Span J Agric Res 4: 235-247. DOI: 10.5424/sjar/2006043-198.

Kim H, Cho J. 2010. Simple and rapid detection of Listeria monocytogenes in fruit juice by real time PCR without enrichment culture. Food Control 21: 1419-1423. DOI: 10.1016/j.food cont.2010.04.006.
Kusnandar F. 2010. Kimia Pangan Komponen Makro. 109-112. Jakarta (ID): Dian Rakyat.

Montero D, Bodero M, Riveros G, Lapierre L, Gaggero A, Vidal RM, Vidal M. 2015. Molecular epidemiology and genetic diversity of Listeria monocytogenes isolates from a wide variety of ready-to-eat foods and their relationship to clinical strains from listeriosis outbreaks in Chile. Front Microbiol 6: 384 . DOI: $10.3389 / \mathrm{fmicb}$. 2015.00384.

Mutsyahidan AMA, Rahayu WP, Nurjanah S. 2016. Detection of Listeria monocytogenes in indigenous Indonesian snack using real time polymerase chain reaction. Malaysian $\mathrm{J}$ Microb 12: 177-181. DOI: $10.21161 / \mathrm{mjm} .78415$.

Nadal A, Coll A, Cook N, Pla M. 2007. A molecular beacon-based real time NASBA assay for detection of Listeria monocytogenes in food products: Role of target mRNA secondary structure on NASBA design. J Microbiol Meth 68: 623-632. DOI: 10.1016/j.mimet.2006.11. 011.

Queero GM, Santovito E, Visconti A, Fusco V. 2014. Quantitative detection of Listeria monocytogenes in raw milk and soft cheeses: Cultureindependent versus liquid- and solid-based culture-dependent real time PCR approaches. LWT-Food Sci Technol 58: 11-20. DOI: 10. 1016/j.Iwt.2014.03.005.

Ragon M, Wirth T, Hollandt F, Lavenir R, Lecuit M, Monnier AL, Brisse S. 2008. A new perspective on Listeria monocytogenes evolution. Plos Pathog 4: e1000146. DOI: 10.1371/journal. ppat. 1000146.

Rahayu WP, Nurjanah S, Nurwitri CC. 2015. Kajian Risiko Listeria monocytogenes pada Pangan Jajanan Anak Sekolah Berbasis Ikan. Laporan Hibah Kompetensi DIKTI.

Shi Y, Tang J, Yue T, Rasco B, Wang S. 2015. Pasteurizing cold smoked salmon (Onchorynchus nerka): thermal inactivation kinetics of Listeria monocytogenes and Listeria innocua. J Aquat Food Prod T 24: 712-722. DOI: 10.1080/ 10498850.2013.808303.

Tocmo R, Krizman K, Khoo WJ, Phua LK, Kim M, Yuk H. 2014. Listeria monocytogenes in vacuum-packed smoked fish products: occurrence, routes of contamination, and potential intervention measures. Compr Rev Food Sci F 13: 172-189. DOI: 10.1111/15414337.12052.

Zilelidou EA, Rychli K, Manthou E, Ciolacu L, Wagner M, Skandamis PN. 2015. Highly invasive Listeria monocytogenes strains have growth and invasion advantages in strain competition. PlosOne 10: e0141617. DOI: 10. 1371/journal.pone.0141617. 